\title{
Zespół Wunderlicha z objawami wstrząsu septycznego jako pierwszy objaw raka jasnokomórkowego nerki — opis przypadku klinicznego
}

\author{
Norbert Foltyński, Stanisław Wawryka
}

Samoistne krwawienie z miąższu nerki manifestujące się jako zespółWunderlicha jest niezwykle rzadkie. Najczęstszą przyczyną krwawienia jest angiomiolipoma. Rzadszą przyczyną jest polekowe zapalenie naczyń, rak nerki, guz chromochłonny lub torbiel nerki prosta. Przedstawiamy przypadek kliniczny 40-letniego mężczyzny z objawami wstrząsu septycznego z powodu zakażonego krwiaka nerki jako pierwszy objaw raka jasnokomórkowego nerki.

\section{Wunderlich Syndrome with symptoms of septic shock as the first manifestation of renal cell carcinoma. Case report}

Spontaneous bleeding from the kidney parenchyma manifested as Wunderlich syndrome is extremely rare. The most common cause of bleeding is angiomiolipoma. Less often are drug-induced vasculitis, kidney cancer, pheochromocytoma or renal cyst. We present the case of 40-year old man with symptoms of septic shock due to infected kidney haematoma as the first symptom of renal cell carcinoma.

NOWOTWORY Journal of Oncology 2015; 65, 2: 135-138

Słowa kluczowe: zespół Wunderlicha, rak jasnokomórkowy nerki, nefrektomia

Key words: Wunderlich syndrome, renal cell carcinoma, nephrectomy

\section{Wprowadzenie}

ZespółWunderlicha, znany również jako samoistne pęknięcie i krwiak nerki, jest rzadką chorobą, w której występuje krwawienie do przestrzeni podtorebkowej lub okołonerkowej bez obecności urazu jako czynnika sprawczego [1]. Rzadkość występowania tego schorzenia podkreśla fakt, że do 2003 r. opisano 250 jego przypadków [2]. Choroba ta została po raz pierwszy zaobserwowana przez Boneta w 1700 roku, a po raz pierwszy opisana klinicznie w 1856 r. przez Wunderlicha jako, spontaniczny nagły krwotok podtorebkowy" $[3,4]$. Coenen pierwszy użył nazwy „Wunderlich's Syndrome" w 1910 r. i utrzymuje się ona do dzisiaj [3, 4]. Najczęstszymi typowymi objawami są: ból w okolicy lędźwiowej (53\%), wyczuwalny palpacyjnie guz (47\%) i wstrząs lub masywny krwiomocz (23\%), zwane jako triada Lenka [5]. Inne rzadko występujące objawy towarzyszące to: mdłości, wymioty, gorączka, niedokrwistość, wahania ciśnienia krwi [6]. Zespół powszechnie jest powiązany z różnymi patologiami naczyniowymi, takimi jak nowotwór i choroba na tle naczyniowym [6]. Najczęstszą przyczyną, około 60-65\% z wszystkich przypadków zespołu Wunderlicha, stanowią nowotwory nerek [7]. Przyczyny spontanicznych krwotoków z miąższu nerek przedstawiono w tabeli I. Angiomiolipoma jest najpospolitszym łagodnym nowotworem odpowiedzialnym za WS (ZespółWunderlicha), podczas gdy rak nerkowokomórkowy jest najpospolitszym złośliwym nowotworem [7]. Jednakże częstość zespołu jako powikłanie raka nerkowokomórkowego szacuje się tylko na 0,3-1,4\%, natomiast w przypadku angiomiolipoma sięga ona 13-100\% [2]. Często współistnieje razem z nadciśnieniem (33-50\%) i miażdżycą (80-87\%) [4, 8]. Zespół potwierdza się w standardowych badaniach obrazowych (USG, TK, MR), przy czym TK jest 
Tabela I. Przyczyny spontanicznych krwotoków z miąższu nerek [9]

\begin{tabular}{lc}
\hline Etiologia & Procent (\%) \\
\hline Nowotwory & 61,2 \\
łagodne (głównie AML) & 31,5 \\
$\quad$ złośliwe & 29,7 \\
Choroby naczyniowe & 17,0 \\
$\quad$ (głównie poliarteritis nodosa, tętniaki, & \\
$\quad$ przetoki a-v, zakrzepica żylna) & \\
Infekcje (zapalenie nerek) & 2,42 \\
Idiopatyczne & 6,7 \\
Inne (kamica, zaburzenia krzepnięcia) & 12,7 \\
\hline
\end{tabular}

uważana za złoty standard w ustalaniu diagnozy i często stosowana w celu wyjaśnienia etiologii zespołu [3, 7].

\section{Opis przypadku klinicznego i leczenie}

Chory lat 40 został przyjęty na Oddział Urologii w trybie pilnym z objawami wstrząsu septycznego, bólem okolicy lędźwiowej lewej, nieznaczną anemizacją, gorączkujący od 4 dni do 39,5 st. C. Uraz jamy brzusznej i krwiomocz negował. W wywiadzie - dna moczanowa i wrzodziejące zapalenie jelita grubego. Kilka dni wcześniej zaopatrzony przez lekarza rodzinnego z powodu nagłego silnego bólu okolicy lędźwiowej lewej, traktowanego jako kolka nerkowa. W badaniu fizykalnym zwracał uwagę patologiczny opór okolicy lędźwiowej lewej z dodatnim objawem Goldflama, tachykardia (HR 100/min), niskie ciśnienie tętnicze krwi (95/70 mm Hg).

$\begin{array}{ll}\text { W badaniach laboratoryjnych: } \\ \text { WBC } & 7,2 \text { tys./ul } \\ \text { HB } & 11,1 \mathrm{~g} / \mathrm{dl} \\ \mathrm{Ht} & 31 \% \\ \mathrm{PLT} & 192 \mathrm{tys} . / \mathrm{ul} \\ \mathrm{CRP} & 257,95 \mathrm{mg} / \mathrm{dl} \\ \text { Kreatynina } & 1,02 \mathrm{mg} / \mathrm{dl} \\ \text { Sód } & 138 \mathrm{mmol} / \mathrm{l} \\ \mathrm{K} & 3,6 \mathrm{mmol} / \mathrm{l}\end{array}$

W badaniach obrazowych:

USG przestrzeni zaotrzewnowej — nerka prawa o prawidłowych obrysach, jednorodnej strukturze, bez obecności złogów i poszerzenia UKM. W obrębie nerki lewej niejednorodna struktura w obrębie bieguna górnego. Wokół nerki niejednorodne echogenicznie przestrzenie,częściowo płynowe, sugerujące ropień okołonerkowy.

TK jamy brzusznej i dolnych partii płuc (opis skrócony) — płyn w lewej jamie opłucnowej, około $3 \mathrm{~cm}$.

Nerka lewa:

- okołonerkowy krwiak (nie w pełni jednorodny) grubości około $35 \mathrm{~mm}$ i współczynniku pochłaniania około $60 \mathrm{jH}$,

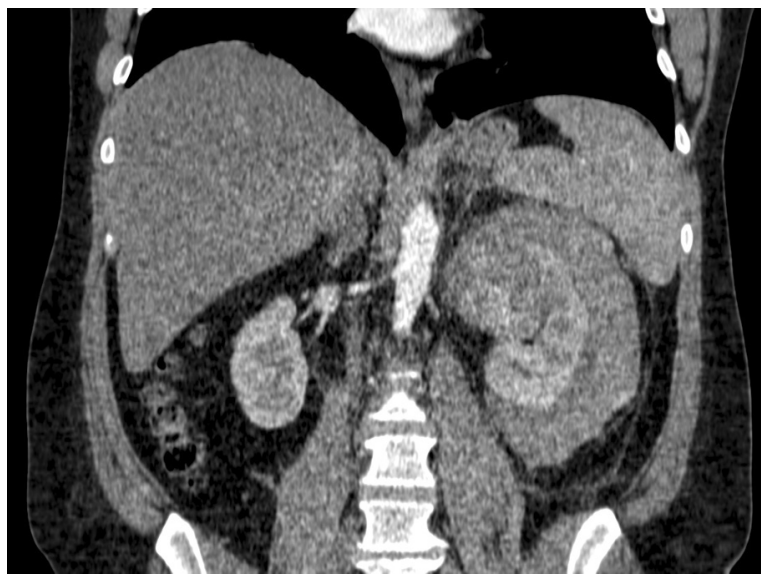

Rycina 1. TK jamy brzusznej. Faza tętnicza — niejednorodny biegun górny (pozycja wieńcowa)

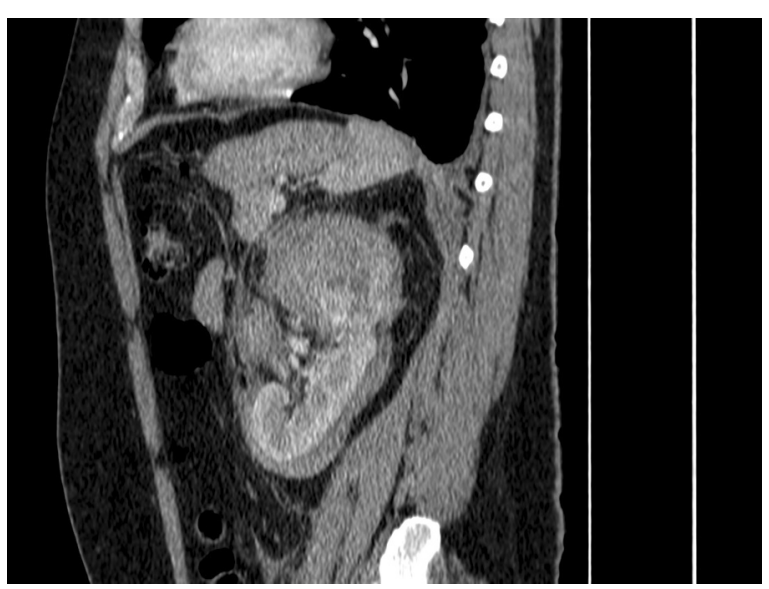

Rycina 2. TK jamy brzusznej. Faza wrotna - niejednorodny biegun górny (pozycja strzałkowa)

- niejednorodna tkanka tłuszczowa okołonerkowa (ropień?, zapalenie okołonerkowe?),

- niejednorodne zakontrastowanie bieguna górnego nerki w fazie tętniczej i wrotnej — zmiany jak w przypadku pęknięcia miąższu,

- nerka wraz z okołonerkowym krwiakiem w osi długiej do $15 \mathrm{~cm}$ i grubości do $10 \mathrm{~cm}$.

Wniosek - krwiak najpewniej zropiały okołonerkowy nerki lewej w przebiegu procesu zapalnego, pourazowy lub na tle zmiany rozrostowej.

Na rycinach 1, 2, 3, 4 przedstawiono zdjęcia z wykonanego badania TK jamy brzusznej.

Pacjenta zakwalifikowano w trybie pilnym do zabiegu operacyjnego. Cięciem Bergmana otworzono okolicę lędźwiową lewą. Po przecięciu warstw mięśniowych i otworzeniu powięzi Geroty ewakuowano zakażonego krwiaka i pobrano śródoperacyjnie posiewy z krwiaka. W większości krwiak był zlokalizowany podtorebkowo. Wy- 


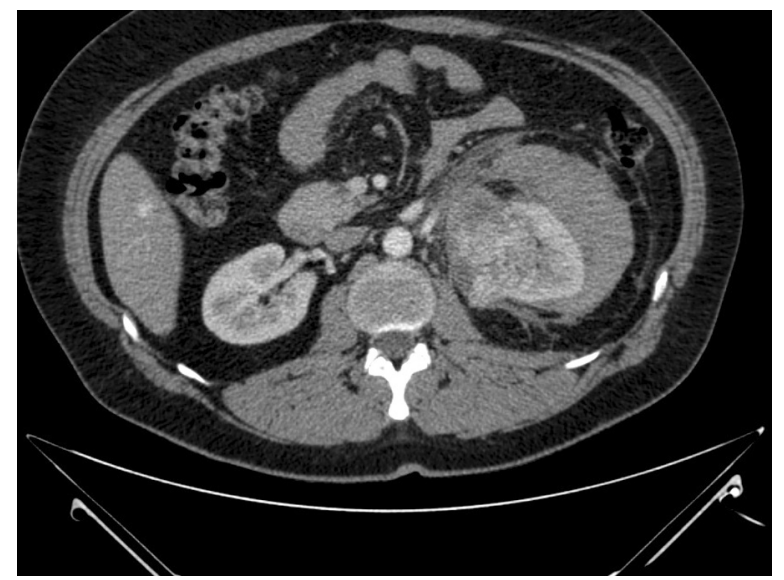

Rycina 3. TK jamy brzusznej. Faza wrotna - pęknięty miąższ (przekrój ax)

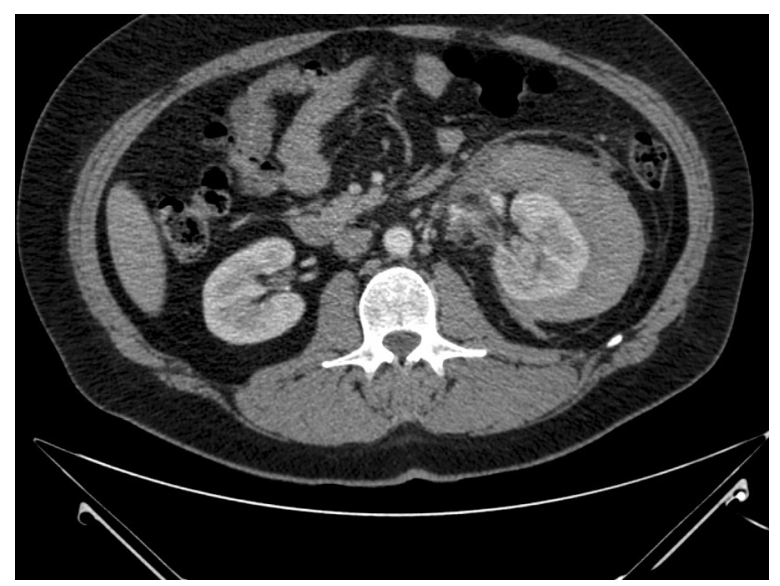

Rycina 4. TK jamy brzusznej. Faza wrotna — zakażony krwiak okołonerkowy (przekrój ax)

preparowano moczowód i nerkę o dużym odczynie zapalnym okołonerkowych tkanek przestrzeni zaotrzewnowej i po przygotowaniu usunięto nerkę. W obrębie górnego bieguna widoczne duże pęknięcie miąższu, na przekroju nerki makroskopowy guz średnicy około $6 \mathrm{~cm}$. W okresie pooperacyjnym stosowano szerokopasmową antybiotykoterapię, przetoczono preparaty osocza mrożonego i preparaty koncentratu krwinek czerwonych. Przebieg hospitalizacji przebiegał bez powikłań.

Wynik histopatologiczny - carcinoma nephrogenes clarocellulare G2

Nerka lewa o wymiarach $12,5 \times 5 \times 5,5 \mathrm{~cm}$. W obrębie górnego bieguna lito-torbielowaty guz o średnicy $6,5 \mathrm{~cm}$ z wylewami krwi, ogniskami szkliwienia, martwicą i metaplazją kostną. Miedniczka nerkowa oraz tkanka tłuszczowa wnęki nerki bez nacieku nowotworowego. W miąższu nerki wokół guza obfite nacieki zapalne i włóknienie kłębków.
W pozostałych częściach miąższu cechy pyelitis chronica - przewlekłego zapalenia nerki. W klasyfikacji TNM rak nerki T1bNOMO.

\section{Podsumowanie}

Zespół Wunderlicha jest bardzo rzadko występującą jednostką chorobową i zazwyczaj pojawia się w łagodnych zmianach. Jego niespecyficzność i niejednoznaczność stanowi duże wyzwanie diagnostyczne i lecznicze. Powyższy przypadek wymagał pilnej interwencji chirurgicznej nie tylko ze względu na objawy krwawienia i niestabilności hemodynamicznej, ale także na symptomy urosepsy. W przedoperacyjnym obrazie klinicznym zespół lekarzy nie przypuszczał, że pod maską samoistnego krwawienia z nerki kryje się rak jasnokomórkowy. Podstawową metodą obrazowania służącą do rozpoznania jest tomografia komputerowa, aczkolwiek niektórzy autorzy zwracają uwagę na trudności wykrycia zmian nowotworowych w czasie epizodu silnego krwotoku.

Stwierdzono, że $60 \%$ badań wykazało nierozpoznane RCC w czasie wstępnej TK [10], co jest zgodne z metaanalizą Zhanga, gdzie TK wykonywane w czasie krwotoków było tylko częściowo skuteczne widentyfikacji nowotworów nerek (czułość 0,57 ) [9]. Rozpoznanie zespołu obliguje do pilnej interwencji zabiegowej. Rodzaj zabiegu zależy od stanu ogólnego pacjenta, stabilności hemodynamicznej i przyczyny krwotoku. Chirurgia endowaskularna jest wskazana w przypadku przyczyn naczyniowych (tętniak, przetoka tętniczo-żylna). Embolizacja (SAE — selektywna embolizacja tętnic) tętnicy nerkowej w przypadku AML jest wskazana w krwawieniach spowodowanych pęknięciem guza (metoda pierwszego rzutu). Embolizacja powoduje jednocześnie zmniejszenie wymiarów guza i może być wykorzystana w przypadku nagłych krwotoków, ale także jako planowe postępowanie terapeutyczne.

W przypadku raków nerkowokomórkowych standardem jest nefrektomia lub zabieg nerkooszczędzający (NSS) u stabilnych hemodynamicznie pacjentów i w guzach w stopniu zaawansowania T1a (do $4 \mathrm{~cm}$ ). Mamy nadzieję, że nasz opis przypadku pomoże ułatwić rozpoznanie u pacjentów zespołu Wunderlicha. Wczesne zastosowanie tomografii komputerowej w odpowiednich okolicznościach i wielodyscyplinarny zespół może pozwolić na zastosowanie mniej inwazyjnych metod leczenia.

\section{Konflikt interesów: nie zgłoszono}

\section{Lek. Norbert Foltyński \\ Oddział Urologii Wojewódzkiego \\ Szpitala Specjalistycznego $\mathrm{nr} 2$ \\ ul. Jana Pawła II 7, 44-335 Jastrzębie Zdrój \\ e-mail:nofo1@wp.pl}

Otrzymano: 4 grudnia 2014 r.

Przyjęto do druku: 9 stycznia 2015 r. 


\section{Piśmiennictwo}

1. Wunderlich CR. Handbuch der Pathologie und Therapie. 2nd ed. Stuttgart: Ebner and Seubert, 1856.

2. Blakeley CJ, Thiagalingham N. Spontaneous retroperitoneal haemorrhage from a renal cyst: an unusual cause of haemorrhagic shock. Emerg Med J 2003; 20: 388.

3. Albi G, del Campo L, Tagarro D. Wunderlich's syndrome: causes, diagnosis and radiological management. Clinical Radiology 2002; 57 : 840-845.

4. Daliakopoulos SI. Spontaneous retroperitoneal hematoma: a rare devastating clinical entity of a pleiada of less common origins. J Surg Tech Case Rep 2011; 3: 8-9.
5. Simmons JL, Hussain SA, Riley P i wsp. Management of renal angiomyolipoma in patients with tuberous sclerosis complex. Oncol Rep 2003; 10: 237-241.

6. Phillips CK, Lepor H. Spontaneous retroperitoneal haemorrhage caused by segmental arterial mediolysis. Rev Urol 2006; 8: 36-40.

7. Katabathina VS, Katre R, Prasad SR i wsp. Wunderlich syndrome: cross-sectional imaging review. J Comput Assist Tomography 2011; 35: 425-433.

8. Timmermans LG. Therapeutic strategy for Wunderlich syndrome. Acta Urol Belg 1997; 65: 73-79.

9. Zhang JQ, Fielding JR, Zou KH. Etiology of spontaneous perirenal hemorrhage: a meta-analysis. J Urol 2002; 167: 1593-1596.

10. Kendall AR, Senay BA, Coll ME. Spontaneous subcapsular renal hematoma: diagnosis and management. J Urol 1988; 139: 246-250. 